\title{
PENGARUH MOTIVASI TERHADAP KINERJA PEGAWAI DI BADAN PERTANAHAN NASIONAL KOTA DEPOK
}

\author{
Jauhary Arifin dan Ruri Trihandayani \\ STIE Unisadhuguna Jakarta, Indonesia \\ Email : jauhary@gmail.com
}

\begin{abstract}
Abstrak
Pendahuluan : Manajemen sumber daya manusia keberadaannya sangat dibutuhkan oleh organisasi/perusahaan baik organisasi/perusahaan pemerintah maupun swasta. Pimpinan harus mampu memanfaatkan sumber daya manusia, dalam hal ini adalah para pegawai dalam meningkatkan pelayanan masyarakat.

Tujuan : Penelitian ini bertujuan untuk mengetahui seberapa besar pengaruh motivasi terhadap kinerja karyawan, serta berguna sebagai sumber informasi dan meningkatkan wawasan tentang motivasi dan kinerja karyawan.

Metode : Metode penelitian yang digunakan adalah kuantitatif asosiatif. Pengumpulan data termasuk penelitian perpustakaan dan studi lapangan dengan mengamati dan mendistribusikan kuesioner atau kuesioner. Sedangkan untuk populasi dalam penelitian ini sebanyak 30 karyawan maka penulis mengambil sampel total 30 responden.

Hasil : Hasil perhitungan analisis regresi linier sederhana yang diperoleh $\mathrm{Y}=$ $0,139+0,958 \mathrm{X} 1$ yang berarti ada pengaruh 0,958 antara variabel motivasi $(\mathrm{X} 1)$ pada variabel kinerja (Y) dan 0,139. Nilai $\operatorname{rxy}^{2} \mathrm{x}$ adalah 0,767 yang berarti ada pengaruh kuat antara motivasi, pada kinerja karyawan. Hasil koefisien penentuan adalah 58,9\%. Ini menunjukkan bahwa motivasi dan gaya kepemimpinan mempengaruhi kinerja karyawan sebesar $58,9 \%$ sementara $41,1 \%$ sisanya dipengaruhi oleh faktor-faktor lain yang tidak diperiksa oleh penulis.

Kesimpulan : Dapat dikatakan bahwa ada faktor-faktor yang mendorong untuk mendapatkan kinerja yang baik, kualitas kerja yang baik adalah bagian dari motivasi prestasi yang merupakan bagian dari kebutuhan individu.
\end{abstract}

Kata kunci : Motivasi; Kinerja Karyawan.

\section{Abstract}

Introduction: Human resource management is needed by organizations / companies both government and private organizations / companies. Leaders must be able to utilize human resources, in this case are employees in improving community services.

Objectives: This research aims to find out how much influence motivation has on employee performance, as well as useful as a source of information and improve insight into employee motivation and performance.

Method: The research method used is quantitatively associative. Data collection includes library research and field studies by observing and distributing questionnaires or questionnaires. As for the population in this study as many as 30 employees, the authors took a total sample of 30 respondents.

Results: The results of a simple linear regression analysis calculation obtained by $Y=0.139+0.958 X 1$ which means there is an influence of 0.958 between the motivation variable $(X 1)$ on the performance variable $(Y)$ and 0.139. The value of 
$r x y^{2} x$ is 0.767 which means there is a strong influence between motivations, on employee performance. The coefficient of determination is $58.9 \%$. It showed that motivation and leadership style affected employee performance by $58.9 \%$ while the remaining $41.1 \%$ were influenced by other factors not examined by the authors.

Conclusion: It can be said that there are factors that drive to get good performance, good quality work is part of the motivation of achievement that is part of the individual needs.

Keywords: Motivation; Employee Performance.

\section{Pendahuluan}

Sebagai sebuah organisasi, instansi pemerintah semakin dituntut untuk memperlihatkan pencapaian keberhasilan tugas pokok dan fungsinya. Keberhasilan sebuah organisasi akan banyak di pengaruhi oleh kemampuannya untuk menyampaikan informasi secara terbuka, seimbang, dan merata bagi semua pihak berkepentingan (stakeholder) (Wijayanto \& SPi, 2013). Pegawai dalam suatu organisasi merupakan aset terpenting dalam pencapaian tujuan sebuah organisasi, dimana pegawai mampu menghasilkan kinerja yang baik dapat memberikan kontribusi besar dalam menjalankan aktivitas suatu organisasi dan juga pegawai merupakan perencana dan pengendali semua kegiatan organisasi (Mantiri, 2019).

Badan Pertanahan Nasional (BPN) atau yang dulunya dikenal dengan sebutan Kantor Agraria ini adalah lembaga pemerintah non kementerian di Indonesia yang mempunyai tugas dan fungsi di bidang pertanahan secara nasional, regional dan sektoral. Untuk tingkat regional disebut Kantor Wilayah Badan Pertanahan Nasional Kota Depok.

Manajemen sumber daya manusia keberadaannya sangat dibutuhkan oleh organisasi/perusahaan baik organisasi/perusahaan pemerintah maupun swasta (Indrajaya \& Adnyani, 2013). Di dalam suatu perusahaan terdapat atasan dan bawahan, untuk meraih tujuan tersebut diperlukan suatu kerjasama yang baik antara atasan dan bawahan tersebut (Lubis, 2015). Selain kerjasama, juga diperlukan suatu motivasi kerja serta bentuk kepemimpinan unggul karena dengan hal-hal tersebut dapat memberikan kinerja yang baik pada organisasi yang tentu saja akan berdampak positif bagi organisasi (Setiawan, 2013). Menurut (Muizu, Titisari, \& Sule, 2018) Kinerja pegawai dalam perusahaan merupakan hal yang sangat penting karena akan bermanfaat untuk mengetahui efektifitas kerja organisasi sehingga tujuan organisasi tersebut akan dapat tercapai.

Oleh sebab itu setiap (Agustini, 2019) mengungkapkan pimpinan harus mampu memanfaatkan sumber daya manusia, dalam hal ini adalah para pegawai dalam meningkatkan pelayanan masyarakat. Agar supaya pegawai dapat lebih efektif dalam melakukan tugasnya, maka pimpinan harus memahami situasi dalam organisasi atau instansi pemerintah Badan Pertanahan kota Depok khususnya.

Tabel 1 Absensi Pegawai Tidak Tetap Bpn Kota Depok 2014-2016

No. Tahun Sakit Ijin Cuti Tanpa




\begin{tabular}{llllll}
\hline & & & & & Keterangan \\
\hline 1 & 2014 & $25 \%$ & $5 \%$ & $5 \%$ & $25 \%$ \\
\hline 2 & 2015 & $15 \%$ & $8 \%$ & $10 \%$ & $40 \%$ \\
\hline 3 & 2016 & $20 \%$ & $6 \%$ & $0 \%$ & $50 \%$ \\
\hline \multicolumn{6}{c}{ Sumber: BPN Kota Depok }
\end{tabular}

\section{Metode Penelitian}

Metode yang digunakan dalam penelitian ini adalah metode deskriptif kuantitatif (Cresswell, 2017). Metode kuantitatif adalah ilmu dan seni yang berkaitan dengan tata cara (metode) pengumpulan data, analisis data, dan interprestasi hasil analisis untuk mendapatkan informasi guna penarikan kesimpulan dan pengambilan keputusan. Penelitian ini melakukan Survey dengan menggunakan alat kuesioner sebagai instrument pengumpulan data dan hasil itulah yang akan diolah dengan software SPSS 24 (Ghozali, 2018).

\section{Hasil dan Pembahasan}

\section{A. Uji Validitas}

Dalam penelitian uji validitas dilakukan terhadap instrumen penelitian variabel X dan Y dengan bantuan software SPSS 24 (Santoso, 2014).

Adapun dasar pengambilan keputusan adalah:

a. Jika $r$ hitung $>\mathrm{r}$ tabel maka pernyataan tersebut valid

b. Jika $r$ hitung $<\mathrm{r}$ tabel maka pernyataan tersebut tidak valid.

Tabel 2

Hasil Pengujian Validitas

\begin{tabular}{ccccc}
\hline No & Variabel & R. Hitung & R. Tabel & Keterangan \\
\hline 1. & Motivasi $\left(\mathbf{X}_{\mathbf{1}}\right)$ & & & \\
\hline & $\mathrm{X}_{1.1}$ & 0,742 & 0,361 & Valid \\
\hline & $\mathrm{X}_{1.2}$ & 0,706 & 0,361 & Valid \\
\hline $\mathrm{X}_{1.3}$ & 0,494 & 0,361 & Valid \\
\hline $\mathrm{X}_{1.4}$ & 0,706 & 0,361 & Valid \\
\hline $\mathrm{X}_{1.5}$ & 0,434 & 0,361 & Valid \\
\hline $\mathrm{X}_{1.6}$ & 0,675 & 0,361 & Valid \\
\hline $\mathrm{X}_{1.7}$ & 0,742 & 0,361 & Valid \\
\hline $\mathrm{X}_{1.8}$ & 0,706 & 0,361 & Valid \\
\hline $\mathrm{X}_{1.9}$ & 0,494 & 0,361 & Valid \\
\hline $\mathrm{X}_{1.10}$ & 0,549 & 0,361 & Valid
\end{tabular}

Sumber: Diolah Oleh Penulis

Variabel Motivasi (X) berjumlah 10 butir pernyataan yaitu nomor butir pernyataan dimulai dari 1 sampai dengan nomor 10. Berdasarkan tabel 4.1 dapat dilihat bahwa semua butir pernyataan untuk variabel Motivasi (X) dinyatakan valid karena berdasarkan hasil perhitungan SPSS semua butir pernyataan yang ada memiliki nilai $r$ hitung $>\mathrm{r}$ tabel.

\section{Tabel 3}

Hasil Pengujian Validitas

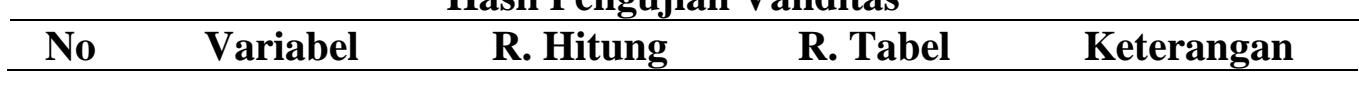




\begin{tabular}{cccc}
\hline 1. Motivasi $\left(\mathbf{Y}_{\mathbf{1}}\right)$ & & & \\
\hline $\mathrm{Y}_{1.1}$ & 0,783 & 0,361 & Valid \\
\hline $\mathrm{Y}_{1.2}$ & 0,571 & 0,361 & Valid \\
\hline $\mathrm{Y}_{1.3}$ & 0,464 & 0,361 & Valid \\
\hline $\mathrm{Y}_{1.4}$ & 0,436 & 0,361 & Valid \\
\hline $\mathrm{Y}_{1.5}$ & 0,464 & 0,361 & Valid \\
\hline $\mathrm{Y}_{1.6}$ & 0,545 & 0,361 & Valid \\
\hline $\mathrm{Y}_{1.7}$ & 0,543 & 0,361 & Valid \\
\hline $\mathrm{Y}_{1.8}$ & 0,507 & 0,361 & Valid \\
\hline $\mathrm{Y}_{1.9}$ & 0,604 & 0,361 & Valid \\
\hline $\mathrm{Y}_{1.10}$ & 0,555 & 0,361 & Valid
\end{tabular}

Sumber: Diolah Oleh Penulis

Variabel Kinerja pegawai (Y) berjumlah 10 butir pernyataan yaitu nomor butir pernyataan dimulai dari 1 sampai dengan nomor 10 . Berdasarkan tabel 4.2 dapat dilihat bahwa semua butir pernyataan untuk variabel Kinerja pegawai (Y) dinyatakan valid karena berdasarkan hasil perhitungan SPSS semua butir pernyataan yang ada memiliki nilai $r$ hitung $>\mathrm{r}$ tabel.

\section{B. Uji Reliabilitas}

Uji Reliabilitas digunakan untuk mengetahui adanya konsistensi alat ukur dalam penggunaannya, atau dengan kata lain alat ukur tersebut mempunyai hasil yang konsisten apabila digunakan berkali-kali pada waktu yang berbeda. Logikanya jika kita lakukan penelitian yang sama, dengan tujuan yang sama dan karakteristik responden yang sama, maka hasil pengambilan data berikutnya akan kita dapatkan respon yang kurang lebih sama (Validitas, 2013).

Cara mengukur reliabilitas yang paling umum adalah dengan menggunakan Koefisien Alpha atau Alpha Cronbach's jika nilai Alpha Cronbach's lebih besar dari 0,60 (tolak ukur) maka instrument tersebut adalah Reliabel dan sebaliknya jika nilai Alpha Cronbach's lebih kecil dari 0,6 maka instrumen tersebut adalah Tidak Reliabel (Heo, Kim, \& Faith, 2015). Dengan kata lain dasar pengambilan keputusannya adalah sebagai berikut:

- Jika Alpha Cronbach's positif atau lebih besar dari batas minimal $(0,600)$ maka reliable

- Jika Alpha Cronbach's negatif atau lebih kecil dari batas minimal $(0,600)$ maka tidak reliabel.

Dari hasil uji reliabilitas yang dilakukan diperoleh hasil sebagai berikut:

Tabel 4

Uji Realibilitas Motivasi (X) Reliabillity Statistics

Cronbach's Alpha .837
$\mathrm{N}$ of Item $\mathrm{s}$

10

Berdasarkan dari output diatas, diketahui bahwa nilai Alpha sebesar 0,827, kemudian nilai ini kita bandingkan dengan nilai $r$ tabel dengan nilai $\mathrm{N}=30$ dicari pada distribusi nilai rtabel signifikansi 5\%, diperoleh nilai rtabel sebesar 0,361. Kesimpulannya Alpha $=0,827>$ rtabel $=0,361$. Artinya variabel Motivasi $(X)$ 
dapat dikatakan reliabel atau terpercaya sebagai alat pengumpul data dalam penelitian.

Tabel 5

Uji Realibilitas Kinerja (Y)

\begin{tabular}{cc}
\hline \multicolumn{2}{c}{ Reliabillity Statistics } \\
\hline Cronbach's Alpha & N of Item s \\
.713 & 10 \\
\hline
\end{tabular}

Berdasarkan dari output diatas, diketahui bahwa nilai Alpha sebesar 0,713, kemudian nilai ini kita bandingkan dengan nilai $r$ tabel dengan nilai $\mathrm{N}=30$ dicari pada distribusi nilai rtabel signifikansi 5\%, diperoleh nilai rtabel sebesar 0,361. Kesimpulannya Alpha $=0,713>$ rtabel $=0,361$. Artinya variabel Kinerja pegawai (Y) dapat dikatakan reliabel atau terpercaya sebagai alat pengumpul data dalam penelitian.

\section{Analisis Krakteristik Responden}

Pada penelitian ini, pembahasan statistik deskriptif dibagi kedalam dua bagian. Pertama, pembahasan statistik deskriptif dilakukan untuk menjelaskan dan menggambarkan berbagai karakteristik responden secara keseluruhan. Kedua, pembahasan deskriptif juga dilakukan untuk mengetahui sebaran jawaban responden dan seberapa jauh variasi jawaban responden dari setiap variabel penelitian ini (Ghozi \& Sunindyo, 2015).

Profil pelanggan ini dibuat oleh peneliti dengan tujuan untuk mengetahui karakteristik dari para konsumen yang berpartisipasi dalam pengisian kuesioner yang disebar oleh peneliti. Peneliti menyebar sebanyak 20 kuesioner kepada 30 responden yang diambil sebagai sampel, dimana 30 responden tersebut adalah responden responden yang bekerja di Badan Pertanahan Nasional Kota Depok. Penggolongan terhadap responden didasarkan berdasarkan data demografi responden yaitu jenis kelamin, usia, latarbelakang pendidikan, pekerjaan, dan penghasilan perbulan. Dari penggolongan ini akan diperoleh suatu kesimpulan keadaan responden.

\section{Karakteristik Berdasarkan Jenis Kelamin}

Hasil pengolahan data yang melibatkan 30 responden tersebut adalah responden responden yang bekerja di Badan Pertanahan Nasional Kota Depok .diperoleh sebanyak $60 \%$ didominasi oleh jenis kelamin laki-laki dan didominasi oleh jenis kelamin perempuan sebanyak 40\%. Berikut adalah tabel 4.5 karakteristik responden berdasarkan jenis kelamin.

Tabel 6

Karakteristik responden berdasarkan jenis kelamin

\begin{tabular}{ccc}
\hline Jenis Kelamin & Jumlah & Persentase \\
\hline Pria & 18 & $60 \%$ \\
\hline
\end{tabular}




\begin{tabular}{ccc}
\hline Wanita & 12 & $40 \%$ \\
\hline Jumlah & 30 & $100 \%$ \\
\hline
\end{tabular}

Sumber: Diolah Oleh Penulis

\section{E. Karakteristik Berdasarkan Usia}

Hasil pengolahan data yang melibatkan 30 tersebut adalah responden responden yang bekerja di Badan Pertanahan Nasional Kota Depok secara keseluruhan diperoleh sebanyak 30\% didominasi oleh usia produktif yang berkisar di bawah 25 tahun, $60 \%$ oleh usia di bawah 35 tahun, $10 \%$ oleh usia diatas 35 tahun. Berikut adalah tabel 6

Tabel 6

Karakteristik responden berdasarkan usia

\begin{tabular}{ccc}
\hline Umur & Jumlah & Persentase \\
\hline Kurang dari 25 tahun & 9 & $30 \%$ \\
\hline Di bawah 35 tahun & 18 & $60 \%$ \\
\hline Diatas 35 & 3 & $10 \%$ \\
\hline Jumlah & 30 & $100 \%$ \\
\hline
\end{tabular}

Sumber: Diolah Oleh Penulis

\section{F. Karakteristik Berdasarkan Pendidikan}

Hasil pengolahan data yang melibatkan 30 responden adalah responden responden yang bekerja di Badan Pertanahan Nasional Kota Depok diperoleh sebanyak $17 \%$ adalah berlatar belakang pendidikan SMA atau sederajat, berlatar belakang Diploma sebesar 63\%, berlatar belakang Sarjana sebesar 20\%. Berikut adalah tabel 7.

Tabel 7

Karakteristik responden berdasarkan pendidikan

\begin{tabular}{lcc}
\hline \multicolumn{1}{c}{ Pendidikan Terakhir } & Jumlah & Persentase \\
\hline SMA/Sederajat & 5 & $17 \%$ \\
\hline D3 & 19 & $63 \%$ \\
\hline S1 & 22 & $22 \%$ \\
\hline S2 & 6 & $20 \%$ \\
\hline Jumlah & 30 & $100 \%$ \\
\hline
\end{tabular}

Sumber: Diolah Oleh Penulis

\section{G. Karakteristik berdasarkan penghasilan}

Hasil pengolahan data yang melibatkan 30 responden adalah responden responden yang bekerja di Badan Pertanahan Nasional Kota Depok secara keseluruhan diperoleh sebanyak $50 \%$ adalah yang yang berpenghasilan kisaran Rp.2.000.000 - Rp.3.000.000, 30\% yang berpenghasilan kisaran Rp.3.000.000 Rp.5.000.000, sebesar 20\% yang berpenghasilan kisaran diatas Rp.5000.000. Berikut adalah tabel 4.8

Tabel 8

Karakteristik responden berdasarkan penghasilan

\begin{tabular}{ccc}
\hline Penghasilan & Jumlah & Persentase \\
\hline Rp. $2.000 .000-$ Rp. 3.000 .000 & 15 & $50 \%$ \\
\hline
\end{tabular}




\begin{tabular}{lcc}
\hline Rp. 3.000.000-Rp. 5.000.000 & 9 & $30 \%$ \\
\hline$>$ Rp. 5.000.000 & 6 & $20 \%$ \\
\hline Jumlah & 30 & $100 \%$ \\
\hline
\end{tabular}

Sumber: Diolah Oleh Penulis

\section{H. Analisis Deskripsi Variabel Motivasi}

Penelitian ini mengukur variabel motivasi berdasarkan penilaian dari responden mengenai motivasi pegawai tidak tetap di Badan Pertanahan Nasional Kota Depok. Variabel motivasi pada penelitian ini diukur melalui 10 buah item pernyataan. Hasil jawaban dan analisis frekuensi jawaban terhadap variabel motivasi dapat dijelaskan sebagai berikut.

Selanjutnya, total nilai pernyataan dari beberapa kategori jawaban dibagi 300 (jumlah keselurhan total nilai jawaban) lalu dikalikan $100 \%$

$\begin{array}{ll}\text { Sangat Tidak Setuju } & =\frac{0}{300} \times 100 \% \\ & =0 \% \\ \text { Tidak Setuju } & =\frac{0}{300} \times 100 \% \\ & =0 \% \\ \text { Kurang Setuju } & =\frac{0}{300} \times 100 \% \\ \text { Setuju } & =0 \% \\ \text { Sangat Setuju } & =\frac{126}{300} \times 100 \% \\ & =42 \% \\ & =\frac{174}{300} \times 100 \% \\ & =58 \%\end{array}$

Dari data diatas penulis menyimpulkan motivasi kerja pada instansi Badan Pertanahan Nasional Kota Depok sudah sesuai yang diharapkan, hal ini di tunjukan dari jawaban 30 responden dapat diketahui motivasi kerja di tandai dengan banyaknya pernyataan yang dijawab dengan kata Sangat Setuju sebesar $58 \%$.

\section{Analisis Deskripsi Variabel Kinerja}

Penelitian ini mengukur variabel kinerja berdasarkan penilaian dari responden mengenai kinerja pegawai tidak tetap di Badan Pertanahan Nasional Kota Depok. Variabel kinerja pada penelitian ini diukur melalui 10 buah item pernyataan. Hasil jawaban dan analisis frekuensi jawaban terhadap variabel kinerja dapat dijelaskan sebagai berikut.

Dari hasil penyebaran kuesioner dengan 10 pernyataan tentang kinerja pegawai yang diberikan kepada 30 responden didapatkan perhitungan sebagai berikut: Jumlah seluruh pernyataan $=163+113+9+12+3=300$.

Selanjutnya, total nilai pernyataan dari beberapa kategori jawaban dibagi 300 (jumlah keselurhan total nilai jawaban) lalu dikalikan $100 \%$

$\begin{aligned} \text { Sangat Tidak Setuju } & =\frac{3}{300} \times 100 \% \\ & =1 \% \\ \text { Tidak Setuju } & =\frac{12}{300} \times 100 \% \\ & =4 \%\end{aligned}$




$\begin{array}{ll}\text { Kurang Setuju } & =\frac{9}{300} \times 100 \% \\ & =3 \% \\ \text { Setuju } & =\frac{113}{300} \times 100 \% \\ & =38 \% \\ \text { Sangat Setuju } & =\frac{163}{300} \times 100 \% \\ & =54 \%\end{array}$

Dari data diatas penulis menyimpulkan motivasi kerja pada instansi Badan Pertanahan Nasional Kota Depok sudah sesuai yang diharapkan, hal ini di tunjukan dari jawaban 30 responden dapat diketahui kinerja pegawai di tandai dengan banyaknya pernyataan yang dijawab dengan kata Sangat Setuju sebesar $54 \%$.

\section{J. Uji Normalitas}

Uji normalitas adalah pengujian tentang kenormalan distribusi data (Nasrum, 2018). Penggunaan uji normalitas karena pada analisis statistik parametik, asumsi yang harus dimiliki oleh data adala bahwa data tersebut harus terdistribusi secara normal. Maksud data terdistibrusi secara normal adalah bahwa data akan mengikuti bentuk distribusi normal.Uji normalitas bisa dilakukan dengan dua cara yaitu dengan "Normal P-P Plot" dan "Tabel Kolmogorov Smirnov". Yang paling umum digunakan adalah Normal P-P Plot.

Normalitas pada umumnya menggambarkan sebaran data yang diperoleh dari hasil kuesioner yang di sebarkan kepada responden. Uji normalitas pada penelitian ini menggunakan uji Kolmogorov Smirnov dengan nilai signifikansi melebihi batas 0,05 maka data yang diteliti memenuhi asumsi normalitas (Ghozali, 2016).

Tabel 9

One-Sample Kolmogrov-Smirnov Test

\begin{tabular}{llrr}
\hline & & Motivasi & \multicolumn{1}{c}{ Kinerja } \\
\hline $\mathrm{N}$ & & 30 & 30 \\
\hline Normal & Mean & 45.8000 & 44.0333 \\
\cline { 2 - 4 } Parameters & Stb. Deviation & 3.10061 & 3.87283 \\
\hline Most Extreme & Absolute & .128 & .095 \\
\cline { 2 - 4 } Differences & Positive & .102 & .062 \\
\cline { 2 - 4 } & Negative & -.128 & -.095 \\
\hline Test Statistic & & .128 & .095 \\
\hline Asymp. Sig. (2-tailed) & $.200^{\mathrm{c}, \mathrm{d}}$ & $.200^{\mathrm{c}, \mathrm{d}}$ \\
\hline
\end{tabular}

a. Test distribution is normal

b. Calculated from data

c. Lilliefors Significance Correction

d. This is a lower bound of the true significance.

Berdasarkan tabeldiatas bahwa hasil uji normalitas menggunakan uji statistik non-paremetik one sample Kolmogorov-smirnov diperoleh nilai Asymp.Sig motivasi. (2-tailed) sebesar 0,200 yang berarti lebih besar dari 0,05 dan nilai Asymp.Sig kinerja sebesar 0,200 berarti lebih besar dari 0,05. Jadi, dapat disimpulkan bahwa data dalam penelitian ini telah terdistribusi dengan normal.

\section{K. Uji Heteroskedastisitas}


Uji Heteroskedastisitas merupakan salah satu bagian dari uji asumsi klasik model regresi. Untuk mendeteksi ada tidaknya heteroskedastisitas dalam sebuah data, peneliti melakukan cara Uji Glejser. Uji ini bertujuan untuk menguji apakah dalam model regresi terjadi ketidaksamaan varian dari residual satu pengamatan ke pengamatan yang lain. Jika varian dari residual satu pengamatan ke pengamatan yang lain tetap maka disebut homoskedastisitas dan berbeda heteroskedastisitas. Model regresi yang baik seharusnya tidak terjadi heteroskedastisitas seperti berikut:

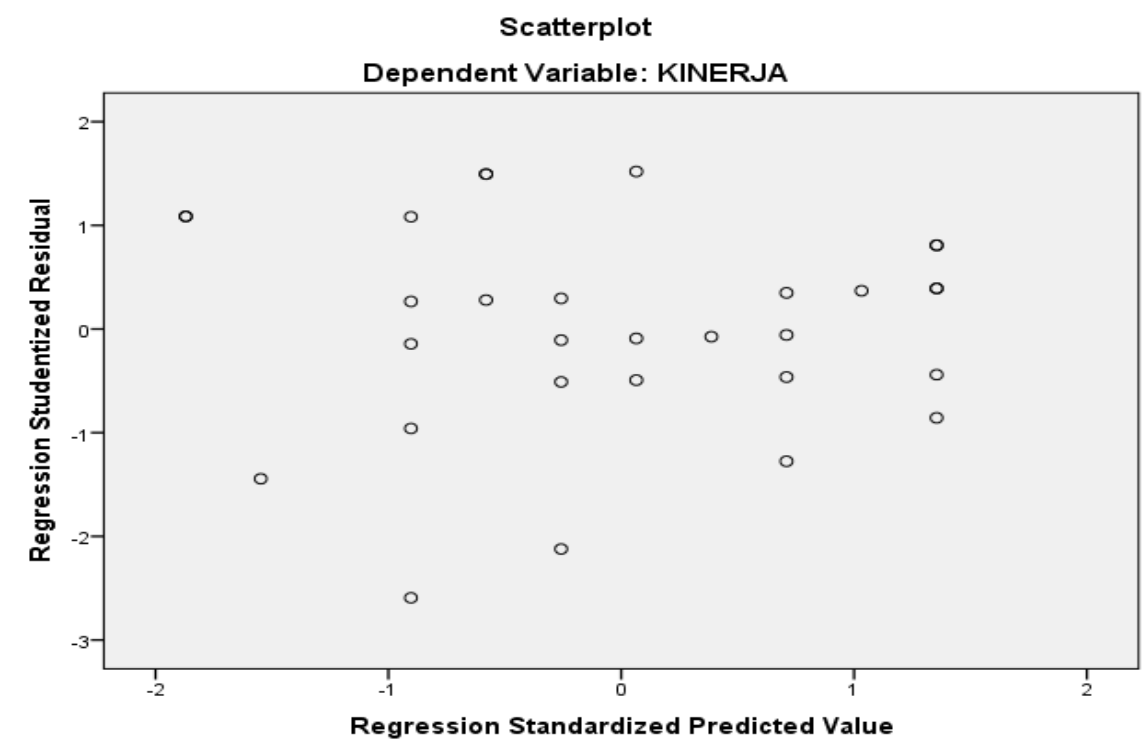

\section{Hasil Uji Heteroskedastisitas}

Dari output diatas dapat diketahui bahwa titik-titik tidak membentuk pola yang jelas, dan titik-titik menyebar diatas dan dibawah angka 0 pada sumbu Y. Jadi dapat disimpulkan bahwa tidak terjadi masalah heteroskedastisitas dalam model regresi. sehingga model regresi layak dipakai untuk memprediksi.

\section{Uji Analisis Regresi Linier Sederhana}

\section{Analisis Regresi Linier Sederhana}

Uji analisis regresi linier sederhana yang pertama penulis bahas adalah pengaruh variabel X (Motivasi) terhadap variabel Y (Kinerja pegawai).

Berikut merupakan hasil uji analisis regresi linier sederhana untuk variabel Motivasi dengan Kinerja pegawai:

Berikut adalah perhitungan seperti tabel dibawah ini:

\section{Tabel 10}

Coefficients $^{\mathrm{a}}$

\begin{tabular}{|c|c|c|c|c|c|}
\hline \multirow[b]{2}{*}{ Model } & \multicolumn{2}{|c|}{$\begin{array}{l}\text { Unstandardized } \\
\text { Coefficients }\end{array}$} & $\begin{array}{l}\text { Standardized } \\
\text { Coefficients }\end{array}$ & $\mathrm{t}$ & Sig. \\
\hline & B & Std. Error & Beta & & \\
\hline
\end{tabular}




\begin{tabular}{llllll}
\hline 1 (Constant) & .139 & 6.948 & & .020 & .984 \\
\hline Motivasi & .958 & .151 & .767 & 6.331 & .000 \\
\hline
\end{tabular}

a. Predictors: (Constant). Motivasi

b. Dependent Variable: Kinerja

Dari tabel dapat dirumuskan suatu persamaan regresi untuk mengetahui pengaruh Motivasi terhadap Kinerja pegawai, yaitu:

Dimana :

$Y=a+b x$

$$
Y=0,139+0,958 x
$$

Keterangan:

$Y=$ Kinerja pegawai

$a=$ Konstanta

$b=$ Koefisien

$x=$ Motivasi

$n=$ Jumlah responden

Konstanta sebesar 0,139 menyatakan bahwa jika variabel bebas dianggap konstan maka Kinerja Pegawai sebesar 0,139 koefisien regresi Motivasi sebesar 0,958 menyatakan bahwa jika motivasi naik $1 \%$ maka akan meningkatkan Kinerja Pegawai sebesar 0,958

\section{Analisis Korelasi}

Untuk mengetahui kekuatan korelasi antara variabel independent (Motivasi) dan variabel dependent (Kinerja Pegawai) secara interval dapat dilihat pada tabel sebagai berikut :

\section{Tabel 11}

Pedoman Nilai Koefisien Korelasi dan Tingkat Hubungan

\begin{tabular}{ll}
\hline Interval Koefisien & Tingkat Hubungan \\
\hline $0,000-0,199$ & Sangat Rendah \\
\hline $0,200-0,399$ & Rendah \\
\hline $0,400-0,599$ & Sedang \\
\hline $0,600-0,799$ & Kuat \\
\hline $0,800-1,00$ & Sangat Kuat \\
\hline \multicolumn{2}{c}{ Sumber: Sugiyono (2012: 184$)$}
\end{tabular}

Tabel 12

Uji Koefisien Korelasi R

Model Summary ${ }^{\mathrm{b}}$

\begin{tabular}{llrrr}
\hline Model & R & R Square & $\begin{array}{c}\text { Adjusted R } \\
\text { Square }\end{array}$ & $\begin{array}{l}\text { Std. Error of } \\
\text { the Estimate }\end{array}$ \\
\hline 1 & $.767^{\mathrm{b}}$ & .589 & .574 & 2,52759 \\
\hline
\end{tabular}

a. Predictors: (Constant). Motivasi

b. Dependent Variable: Kinerja

Berdasarkan tabel 11 diperoleh angka (R) sebesar 0,767. Hal ini menunjukan bahwa terjadi hubungan yang kuat antara pengaruh motivasi terhadap kinerja pegawai. 


\section{Analisis Koefisien Determinasi $\left(\mathbf{R}^{2}\right)$}

Untuk menghitung seberapa besar antara variabel bauran harga $(\mathrm{X})$ dan keputusan pembelian (Y), dapat dihitung dengan menggnakan rumus koefisien penentu. Dalam perhitungan ini, hasil akhirnya dalam bentuk persentase (\%).

Untuk menghitung Koefisien Determinan (KD) adalah sebagai berikut:

$\mathrm{KD}=\operatorname{rxy}^{2} \mathrm{X} 100 \%$

Keterangan:

$\mathrm{KD}=$ Koefisien Determinasi

$\mathrm{rxy}^{2}=$ kuadrat Koefisien Korelasi

Tabel 13

Uji Determinasi

Model Summary ${ }^{b}$

\begin{tabular}{llrrr}
\hline Model & R & R Square & $\begin{array}{c}\text { Adjusted R } \\
\text { Square }\end{array}$ & $\begin{array}{l}\text { Std. Error of } \\
\text { the Estimate }\end{array}$ \\
\hline 1 & $.767^{\mathrm{b}}$ & .589 & .574 & 2,52759 \\
\hline
\end{tabular}

a. Predictors: (Constant). Motivasi

Hasil analisis regresi pada tabel diatas dihasilkan nilai koefisien determinasi sebesar 0,589 (pengkuadratan dari koefisien korelasi adalah $0,767^{2}$ ). Hal ini berarti bahwa 58,9\% motivasi dapat dijelaskan oleh variabel bebas yang digunakan dalam penelitian. Sedangkan sisanya $(100 \%-58,9 \%=41,1 \%)$ dipengaruhi oleh faktor lain.

\section{N. Uji Hipotesis}

Pengujiaan parsial ini menggunakan uji $\mathrm{T}$ yang bertujuan untuk mengetahui besarnya pengaruh masing-masing variabel independen secara individual (parsial) terhadap variabel dependen. Hasil uji ini pada outpun SPSS 22 dapat dilihat pada tabel coefficients.

Nilai $\mathrm{p}$ value lebih kecil dari levelog significant yang ditentukan dari t hitung (pada kolom $\mathrm{t}$ ) lebih besar dari $\mathrm{t}$ tabel (dihitung dari two-tailed, $\mathrm{df}=\mathrm{n}-\mathrm{k}-1, \mathrm{k}$ merupakan jumlah variabel independen). $\mathrm{Df}=30-1-1=28$, maka t table $=2,04841$. Berikut adalah hasil pengolahan uji statistik $t$ dengan menggunakan tabel coefficient.

\section{Tabel 14}

\section{Coefficients $^{\mathrm{a}}$}

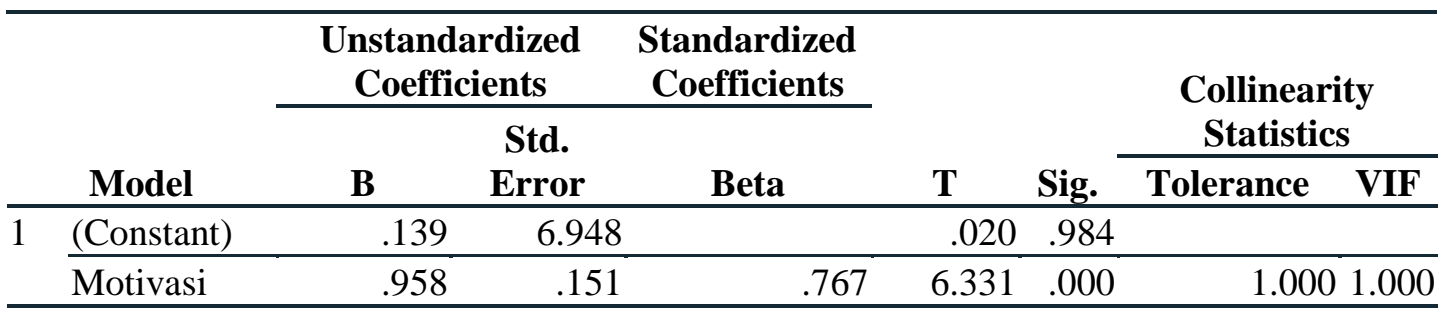

a. Dependent Variable: Kinerja

Berdasarkan hasil analisis pada tabel 14 diatas maka dapat diketahui pengaruh variabel independen secara parsial dan variabel dependen pada uraian berikut ini : 
Pengaruh Motivasi terhadap Kinerja Karyawan

Dari hasil penelitian yang dilakukan oleh penulis, didapat t hitung sebesar 6 , 331 dan didapat $\mathrm{t}$ tabel sebesar 2,04841 yang berarti $\mathrm{t}$ hitung $>\mathrm{t}$ tabel $(6,331>$ 2,04841 ) dan nilai signifikan sebesar 0,000 dimana nilai $0,000<0,05$ menunjukkan bahwa secara parsial variabel Motivasi berpengaruh positif signifikan terhadap kinerja sehingga Ha diterima. Bisa dikatakan adanya faktor yang Mendorong untuk memperoleh prestasi yang bagus,kualitas kerja yang bagus adalah bagian dari motivasi pencapaian dimana bagian dari adanya kebutuhan individu.

\section{Kesimpulan}

Berdasarkan hasil penelitian dan analisis data diatas menyatakan bahwa motivasi kerja pada Pegawai tidak tetap Badan Pertanahan Nasional Kota Depok yang berjumlah 30 pegawai mendapatkan respon yang baik, hal ini berdasarkan hasi jawaban seluruh responden dengan seluruh responden dengan 10 pernyataan, yang menjawab sangat setuju sebanyak 174 atau sebesar 58\%, yang menjawab setuju yaitu sebanyak 126 atau sebesar $42 \%$. dan hasil menunjukan bahwa motivasi pegawai tidak tetap Di BPN Kota Depok sudah mencapai 100\%, maka motivasi pegawai PTT BPN Kota Depok bisa dikatakan sudah sepenuhnya optimal.

Kinerja pada Pegawai tidak tetap Badan Pertanahan Nasional Kota Depok yang berjumlah 30 pegawai mendapat respon yang baik, hal ini diketahui berdasarkan hasil jawaban seluruh responden dengan 10 pernyataan, yang menjawab sangat setuju sebanyak 163 atau sebesar 54\%, yang menjawab setuju yaitu sebanyak 113 atau sebesar 38\% . namun, walaupun kinerja pegawai belum sepenuhnya optimal 100\%, tetapi pegawai merasa kualitas kerja yang dilakukan sudah baik, bersemangat dalam pekerjaannya, dapat memanfaatkan waktu dengan baik dalam bekerja.

Terdapat Pengaruh Motivasi Terhadap Kinerja Pegawai Pada Badan Pertanahan Nasional Kota Depok, analisis data korelasi variable X dan Y hubungnnya "kuat" yaitu ( $r$ ) sebesar 0,767. Persamaan regresi linier sederhana $Y=0,139+0,958 x$ Dapat disimpulkan bahwa jika motivasi kerja ditingkatkan satu satuan maka akan meningkatkan kinerja pegawai sebesar 0,958 dan sebaliknya. didapat t hitung sebesar 6 , 331 dan didapat $t$ tabel sebesar 2,04841 yang berarti $t$ hitung $>t$ tabel $(6,331>2,04841)$ dan nilai signifikan sebesar 0,000 dimana nilai $0,000<0,05$ menunjukkan bahwa secara parsial variabel Motivasi berpengaruh positif signifikan terhadap kinerja yang artinya Ho ditolak dan Ha diterima. Bahwa terdapat pengaruh yang signifikan secara simulutan antara motivasi terhadap kinerja karyawan pada PTT BPN Kota Depok. Dengan demikian dapat disimpulkan bahwa motivasi memiliki pengaruh yang signifikan terhadap kinerja pegawai tidak tetap BPN Kota Depok.

\section{DAFTAR PUSTAKA}

Agustini, Fauzia. (2019). Strategi Manajemen Sumber Daya Manusia. UISU Press. Cresswell, J. W. (2017). Research Design: Pendekatan Kualitatif, Kuantitatif, dan Mixed (Edisi Ketiga). Yogyakarta: Pustaka Belajar. 
Ghozali, Imam. (2016). Aplikasi Analisis Multivariate dengan Program SPSS. Cet . VIII. In Aplikasi Analisis Multivariate dengan Program SPSS. Cet . VIII. Semarang: Badan Penerbitan Universitas Dipanegoro.

Ghozali, Imam. (2018). Aplikasi analisis multivariate dengan program IBM SPSS 25.

Ghozi, Saiful, \& Sunindyo, Aris. (2015). Statistik Deskriptif Untuk Ekonomi. Deepublish.

Heo, Moonseong, Kim, Namhee, \& Faith, Myles S. (2015). Statistical power as a function of Cronbach alpha of instrument questionnaire items. BMC Medical Research Methodology, 15(1), 1-9.

Indrajaya, I. Gusti Agung Aries, \& Adnyani, I. Gusti Ayu Dewi. (2013). Pengaruh Budaya Organisasi, Komunikasi dan Lingkungan Kerja terhadap Produktivitas Kerja Karyawan CV. Hitakara Denpasar. Udayana University.

Lubis, Risa Kartika. (2015). Hubungan antara Kerjasama Karyawan dengan Upaya Pencapaian Tujuan Perusahaan pada PT. Bank Sumut. Jurnal Mantik Penusa, 17(1).

Mantiri, Jeane. (2019). Peran Pendidikan dalam Menciptakan Sumber Daya Manusia Berkualitas di Provinsi Sulawesi Utara. Jurnal Civic Education: Media Kajian Pancasila Dan Kewarganegaraan, 3(1), 20-26.

Muizu, Wa Ode Zusnita, Titisari, Andhita, \& Sule, Ernie T. (2018). Peran Knowlege Sharing Terhadap Kinerja Pegawai Perusahaan Telekomunikasi. INOBIS: Jurnal Inovasi Bisnis Dan Manajemen Indonesia, 1(3), 397-406.

Nasrum, Akbar. (2018). Uji normalitas data untuk penelitian. Jayapangus Press Books, i-117.

Santoso, Singgih. (2014). Panduan Lengkap SPSS versi 20 edisi revisi. Jakarta: PT. Elex Media Komputindo.

Setiawan, Agung. (2013). Pengaruh disiplin kerja dan motivasi terhadap kinerja karyawan pada rumah sakit umum daerah kanjuruhan malang. Jurnal Ilmu Manajemen, 1(4), 1245-1253.

Validitas, Uji. (2013). Reliabilitas. Hasil Uji Validitas Dan Reliabilitas Variabel X, 2.

Wijayanto, Dian, \& SPi, M. M. (2013). Pengantar manajemen. Gramedia Pustaka Utama. 